\title{
Idiopathic Osteoporosis and Nephrolithiasis: Two Sides of the Same Coin?
}

\author{
Domenico Rendina ${ }^{1}$ (D), Gianpaolo De Filippo ${ }^{2,3}{ }^{\mathbb{D}}$, Gabriella Iannuzzo ${ }^{1}$, Veronica Abate ${ }^{1}$, \\ Pasquale Strazzullo ${ }^{1}$ and Alberto Falchetti ${ }^{4,5, * \mathbb{D}}$ \\ 1 Department of Clinical Medicine and Surgery, Federico II University, 80131 Naples, Italy; \\ domenico.rendina@unina.it (D.R.); gabriella.iannuzzo@unina.it (G.I.); veronica.abate.1990@gmail.com (V.A.); \\ strazzul@unina.it (P.S.) \\ 2 Assistance Publique-Hôpitaux de Paris, Hôpital Robert Debré, Service d'Endocrinologie \\ et Diabétologie Pédiatrique, 75019 Paris, France; gianpaolo.defilippo@aphp.fr \\ 3 French Clinical Research Group in Adolescent Medicine and Health, 75014 Paris, France \\ 4 Unit of Bone and Mineral Metabolic Diseases, Istituto Auxologico Italiano, San Giuseppe Hospital, \\ Piancavallo, 28824 Verbania, Italy \\ 5 Istituto Auxologico Italiano, IRCCS, Unit for Bone Metabolism Diseases and Diabetes \& Lab of Endocrine \\ and Metabolic Research, 20145 Milan, Italy \\ * Correspondence: alberto.falchetti2@alice.it; Tel.: +39-33-1689-2204
}

Received: 12 October 2020; Accepted: 30 October 2020; Published: 31 October 2020

\begin{abstract}
Idiopathic osteoporosis and nephrolithiasis are formidable health problems showing a progressive increase in their incidence and prevalence in the last decades. These temporal trends were observed in both pediatric and adult populations worldwide. Epidemiological and experimental studies indicate that both disorders show several common pathogenic environmental and genetic factors. In this review, we analyzed the clinical characteristics common to the two disorders and the state-of-the-art knowledge regarding the genetic predisposition and the environmental factors recognized as triggers in adult and pediatric ages. As a result of this work, we propose to consider idiopathic nephrolithiasis and osteoporosis as two possible expressions of a unique clinical syndrome. Accordingly, the clinical approach to both disorders should be modified in order to program an efficient primary and secondary prevention strategy.
\end{abstract}

Keywords: osteoporosis; nephrolithiasis; adult; children

\section{Introduction}

Idiopathic osteoporosis and nephrolithiasis are formidable health problems characterized by high incidence and prevalence in the adult population worldwide [1]. The pathogenic mechanisms of these two diseases depend on the tight interaction between genetic and environmental factors. In this review, we will analyze the available knowledge regarding the genetic and environmental factors recognized as common triggers for both entities.

\section{Definition and Epidemiological Data}

Osteoporosis is defined as a decrease in bone density that results in micro-architecture deterioration, predisposing the affected patients to fractures [2]. Operationally, osteoporosis has been defined on the basis of a bone mineral density assessment using dual energy $\mathrm{X}$-ray absorptiometry. According to the World Health Organization criteria, in adult subjects, osteoporosis is defined as a bone mineral density that lies 2.5 standard deviations or more below the average value for young healthy subjects (a T-score of $<-2.5$ standard deviations) [3]. This criterion has been widely accepted and provides 
both a diagnostic and an intervention threshold. Osteoporosis is recognized as the most common form of metabolic bone disease, with an estimated 200 million people affected worldwide; in particular, approximately $30 \%$ of postmenopausal women have osteoporosis in industrialized countries, including Europe and United States [4]. Great attention has been recently paid to pediatric osteoporosis and much has changed in the field of pediatric bone health since the first positions of the International Society for Clinical Densitometry were published in 2003 [5]. Some scientific societies have included bone health screening in their clinical guidelines for chronic childhood diseases [6]. Osteoporosis in childhood and adolescence is a condition characterized by a low bone mineral density or bone mineral content (z-score $\leq-2.0$, adjusted for race, age and gender) and the presence of a clinically significant history of skeletal fractures [7]. In the absence of a history of fractures, unlike the T-score in adults, the $\mathrm{z}$-score $<-2$ cannot be used for diagnosis of osteoporosis and thus the preferred term is reduced bone density according to chronological age [8]. Primary osteoporosis in children is a rare condition, recognizing a genetic background. More commonly, secondary osteoporosis (or, more frequently, reduced mineral density) can result from chronic diseases affecting mineral metabolism and/or from significant nutritional perturbations [9].

Nephrolithiasis refers to the presence of crystalline stones (calculi) within the urinary system (kidneys or ureters) [10]. It affects nearly 1 in 11 individuals in the United States at some point in their lives, and there is evidence that the number of those who have had a stone is rising [11]. Similar epidemiological data are available in Europe and in almost all industrialized countries [10-12]. Since the incidence of both osteoporosis and nephrolithiasis increases with age, it is expected that population aging worldwide will lead to a major increase in the incidence of both [1]. In pediatric patients, hospitalization for kidney stone disease has steadily increased [13]. In contrast to the adult kidney stone patient, in which dietary and metabolic factors play a major causal role, genetic-based metabolic disorders are the main causes of childhood nephrocalcinosis and urolithiasis: this notwithstanding, it is conceivable that some of the features of metabolic syndrome, in particular abdominal adiposity, may increasingly contribute to the pathogenesis of such a disorder in the pediatric population [13-15]. The incidence of urolithiasis in pediatric patients is estimated to be approximately one tenth of that in adults. Since the discovery of renal calculi is incidental in up to $40 \%$ of affected children, the real incidence in childhood is likely to be underestimated $[14,15]$.

\section{Natural History and Statistical Evidence}

The natural histories of osteoporosis and nephrolithiasis have many similarities. Both disorders are charged with a high morbidity if not correctly diagnosed and accurately treated. Without a correct clinical and therapeutic approach, at least $40 \%$ of osteoporotic women and $15-30 \%$ of osteoporotic men will sustain one or more fragility fractures in their remaining lifetime [2]. Likewise, as shown by a meta-analysis of nine study cohorts involving 4,770,691 participants overall, stone-forming patients have a significant increased relative risk of chronic kidney disease and, in particular, of end-stage kidney disease compared to individuals without a history of nephrolithiasis [16].

What is much less known is that nephrolithiasis may be considered a risk factor for reduced bone mineral density and osteoporosis [17]. A recent meta-analysis of 24 case-control studies including 1595 patients with nephrolithiasis (590 women; mean age $41.1 \pm 7.6$ years) versus 3402 healthy controls (2109 women; mean age $40.2 \pm 9.2$ years) demonstrated that patients with nephrolithiasis showed significantly lower values of bone mineral density T-scores for the spine (7 studies; 390 patients with nephrolithiasis, 282 controls; standardized mean difference $=-0.69 ; 95 \%$ confidence interval $=-0.86$ to $-0.52 ; \mathrm{I} 2=0 \% ; p<0.05$ ), total hip (seven studies; 521 patients with nephrolithiasis, 323 controls; standardized mean difference $=-0.82 ; 95 \%$ confidence interval $=-1.11$ to $-0.52 ; \mathrm{I} 2=72 \% ; p<0.05$ ), and femoral neck (six studies; 360 patients with nephrolithiasis, 252 controls; standardized mean difference $=-0.67 ; 95 \%$ confidence interval $=-1.00$ to $-0.34 ; \mathrm{I} 2=69 \% ; p<0.05)$. In addition, two studies reported a higher prevalence of osteoporosis in patients with nephrolithiasis compared to controls $(39,960$ patients with osteoporosis, 79,800 controls; odds ratio $=4.12,95 \%$ confidence interval 3.99 to 
$4.26, \mathrm{I} 2=0 \%, p<0.05)$ [17]. However, the same meta-analysis gave conflicting results regarding the relationship occurring between nephrolithiasis and skeletal fractures. Four case-control studies demonstrated that patients with nephrolithiasis are at increased risk of fractures compared to controls (odds ratio $=1.15,95 \%$ confidence interval $=1.12-1.17 ; p<0.05$ ), whereas two longitudinal studies did not confirm the association (hazard ratio $=1.31,95 \%$ confidence interval $=0.95$ to $-1.62 ; \mathrm{I} 2=92 \%$; $p=0.11$ ) [17]. In a subsequent retrospective study involving calcium stone-forming patients, Sakhaee and colleagues found no significant association between urinary calcium excretion and femoral neck or lumbar spine bone mineral density in 250 men and in 145 postmenopausal women treated with estrogens. However, in 37 non-estrogen-treated postmenopausal women, lumbar spine bone mineral density correlated inversely with urinary calcium excretion during a calcium-restricted $\operatorname{diet}(\mathrm{r}=-0.38$, $p=0.04)$ and during fasting $(\mathrm{r}=-0.42, p=0.05)$. These results confirm that nephrolithiasis is a risk factor for reduced bone mineral density and the occurrence of osteoporosis in post-menopausal women [18]. Fewer data are available about the influence of osteoporosis on the risk of nephrolithiasis incidence. Chou and colleagues, evaluating the incidence of symptomatic nephrolithiasis in a cohort of 1634 patients with newly diagnosed osteoporosis (239 men and 1395 women) and in a cohort of 6536 age- and sex- matched subjects without osteoporosis over a 5-year period, demonstrated that osteoporotic patients carry a higher risk of symptomatic nephrolithiasis (adjusted Hazard Ratio 1.38, 95\% confidence interval 1.03 to $1.86 ; p<0.05$ ) [19]. According to Prochaska and colleagues, who carried out a prospective analysis of 96,092 women enrolled in the Nurses' Health Study II, low bone density is an independent risk factor for incident nephrolithiasis (adjusted relative risk 1.39; $95 \%$ confidence interval 1.20 to $1.62, p<0.05$ ) and, among participants with low bone density, treatment with bisphosphonates was associated with a lower risk of kidney stones (adjusted relative risk 0.68; $95 \%$ confidence interval 0.48 to $0.98, p<0.05$ ). [20]. We have recently conducted an epidemiological survey involving 12,165 women and 629 men in Southern Italy (mean age $69.3 \pm 10.0$ years) of whom 10,157 had a clinical diagnosis of idiopathic osteoporosis, showing that osteoporosis is associated with an increased risk of nephrolithiasis (hazard ratio $=1.33,95 \%$ confidence interval 1.01 to $1.74, p<0.05$ ) after adjustment for age, sex, body mass index, treatment for osteoporosis and smoking habits [21].

\section{Pathogenesis}

With regard to pathogenic mechanisms, idiopathic osteoporosis and nephrolithiasis are both multifactorial disorders and share common modifiable and non-modifiable causative factors (Figure 1) [2,10].

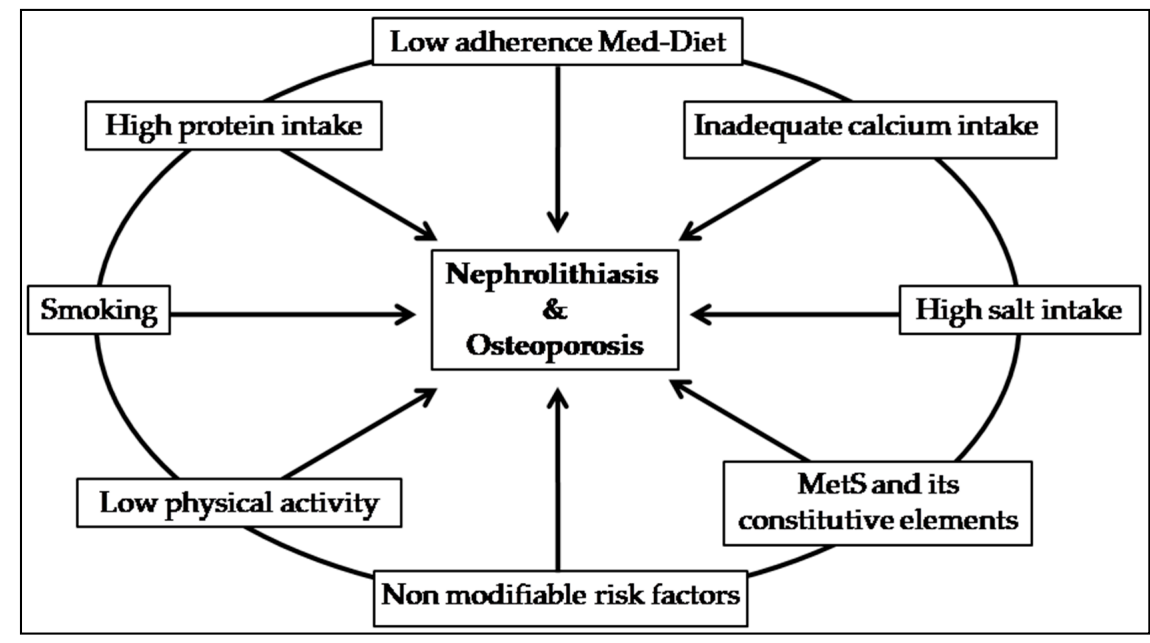

Figure 1. Common pathogenic factors between osteoporosis and nephrolithiasis. Med-Diet: Mediterranean Diet; MetS: Metabolic Syndrome. MetS constitutive elements: diabetes and/or high fasting plasma glucose, abdominal obesity, dyslipidemia and elevated blood pressure. 


\subsection{Modifiable Risk Factors}

Diet. Among the modifiable risk factors, unhealthy eating habits involving high salt, high protein, high sugar and inadequate calcium intakes play a central role in the pathogenesis of both disorders $[10,22]$. Excessive salt intake has been focused on in the last few years as one of the main elements that influence health status [23]; in particular, high salt intake is linked to hypertension and its cardiovascular complications [24]. There is strong evidence of excessive salt intake starting in childhood and adolescence [25]. This is worth special attention, because the effect of the high salt intake will add a high amount of exposure time. Accordingly, many organizations have issued strong recommendations to reduce salt intake [26-29]. Moreover, the harmful relationship between salt intake, osteoporosis and nephrolithiasis is well established [30]. Bone is a target organ of a high dietary sodium intake [31]. Several experimental studies indicate that high salt intake increases urinary calcium excretion, a well-recognized risk factor for both osteoporosis and nephrolithiasis [32,33]. From a physiological point of view, in the renal proximal tubule, calcium handling is strongly dependent on sodium reabsorption [34]. High dietary salt intake induces a high-sodium load to the kidney and a condition of relative hypervolemia. According to the mechanisms of glomerular tubular balance, this condition diminishes the efficacy of sodium and water reabsorption in the proximal tubule [35]. As a consequence, the reabsorption of calcium, whose handling is passively coupled with sodium and water in this part of the nephron, will be less effective. Since, in the distal tubular sections, calcium reabsorption is unrelated to volume status, the final outcome will be a higher urinary calcium excretion [36]. On the other hand, a reduction in dietary salt intake induces relative hypovolemia, thus directly promoting sodium and indirectly calcium reabsorption in the proximal tubule, and subsequently lowering calciuria. The association between salt intake and calcium excretion was first reported by Kleeman and colleagues in 1964 [37]. These authors demonstrated a significant increase in calcium excretion upon the shift from a very-low-salt diet $(1.1 \mathrm{~g} /$ day $(19 \mathrm{mEq} /$ day $))$ to a very-high-salt diet $(24.5 \mathrm{~g} /$ day $(419 \mathrm{mEq} /$ day)). Since then, a large number of intervention studies have reported a linear association between salt intake and calcium excretion in healthy subjects, even for more modest levels of salt intake [38]. It has been suggested that an increase of $6 \mathrm{~g} /$ day $(103 \mathrm{mEq} /$ day $)$ in salt intake may result in a $40 \mathrm{mg} /$ day ( $1 \mathrm{mmol} /$ day) increase in urinary calcium excretion [39]. Moreover, a $3.5 \mathrm{~g}$ $(60 \mathrm{mEq} /$ day $)$ increase in salt intake leads to a 1.63-fold increase in the relative risk of hypercalciuria (defined as an urinary calcium excretion $\geq 7.5 \mathrm{mmol} / 24 \mathrm{~h}$ in men and $\geq 6.25 \mathrm{mmol} / 24 \mathrm{~h}$ in women), healthy subjects with a daily salt intake $>10 \mathrm{~g}(171 \mathrm{mEq})$ having a $21.8 \%$ prevalence in hypercalciuria, compared with a $3.9 \%$ prevalence in those with a lower intake [40]. Other than urinary calcium excretion, a high salt intake is linked to a lower urinary excretion of citrate [41,42], one of the main inhibitors of lithogenesis that, in turn, significantly influences bone mineral mass [43]. Diets with a high salt content or a high content of animal protein impair citrate excretion also by inducing a subclinical intracellular and extracellular acidosis [44]. Hypocitraturia is a risk factor for nephrolithiasis also in children and adolescents: in a group of 493 Polish overweight/obese pediatric patients, the main factor predisposing patients to kidney stones was hypocitraturia [45]. Interestingly, in this group of patients, body mass index standard deviation score (BMI Z-score), total cholesterol, low-density lipoprotein cholesterol and triglycerides correlated negatively with citraturia, while high-density lipoprotein cholesterol correlated positively [45]. There is convincing evidence that increased salt and animal protein intakes are associated with an increased risk of nephrolithiasis [38,46]. This pathogenic link is more evident in stone-forming patients with metabolic syndrome, a significant risk factor for cardiovascular diseases, osteoporosis and nephrolithiasis [47,48]. In particular, in recurrent stone formers with metabolic syndrome, the urinary supersaturation index of calcium-oxalate salts (the most common component of renal calculi) is strictly dependent on the elevated dietary sodium intake and, in these patients, a reduction in sodium intake is associated with a substantial reduction in this index [49]. A recent meta-analysis of the available prospective studies demonstrated that higher dietary sodium intake was associated with significantly increased risk of osteoporosis, though a high degree of heterogeneity among studies was found [50]. Considered as a whole, the studies analyzing 
the association between salt intake and bone metabolism suggest that high dietary salt intake may be associated with impaired bone mineral content, reduced bone mineral density, and increased risk of osteoporosis; these relationships appear to be significantly influenced by anthropometric indices, ethnicity and gender [51]. Calcium intake is one of the main factors affecting the development of peak bone mass and preservation of bone mass in adults [52]. Epidemiological studies demonstrate a progressive reduction in dietary calcium intake with increasing age, resulting in a negative calcium balance $[53,54]$. This mechanism, in turn, significantly increases the risk of osteoporosis and calcium nephrolithiasis over time [55]. Calcium dietary intake is a key factor for oxalate absorption and excretion, oxalate being one of the most potent promoters of calcium nephrolithiasis [56]. A low calcium intake decreases the calcium concentration in the intestinal lumen and prevents the formation of insoluble and non-absorbable calcium-oxalate salts. Consequently, a higher quantity of soluble oxalate salts remains free in the intestinal lumen and can be easily absorbed and excreted by the kidney, increasing the urinary oxalate concentration, a significant metabolic risk factor for nephrolithiasis [57,58].

Moreover, a high dietary intake of simple sugars is another factor able to increase the risk of reduced bone mineral density and osteoporosis [59]. This increased risk has been attributed to the elevated urinary excretion of calcium and magnesium which occurs after the ingestion of common nutritive sugars such as glucose and sucrose [60], to the $1,25 \mathrm{OH}_{2} \mathrm{D}_{3}$-dependent inhibition of intestinal and renal calcium transport, which occurs after a high dietary intake of fructose in experimental models [61], and to the impairment of bone formation caused by the reduced osteoblast proliferation, the increased osteoclast activation, and the increased lactic acid production which has observed in experimental models after high glucose dietary intake and has be linked to impairment of bone strength observed in type 1 and 2 diabetes $[60,62,63]$. In this regard, it should be noted that the regular consumption of soft drinks, a notoriously high source of added sugar, is strongly associated with an increased risk of developing fractures in children and adolescents [64-67] and nephrolithiasis, linked to high urinary calcium excretion, in adults [68,69].

With regard to dietary patterns, a Western type of diet, characterized by a significant share of highly processed and refined foods and high content of sugars, salt, fat and animal protein, has been recognized as an important factor contributing to the development of metabolic disorders such as osteoporosis and nephrolithiasis $[70,71]$. On the contrary, there is growing evidence that a higher adherence to a Mediterranean-type of diet significantly reduces the incidence of nephrolithiasis [72-74] and is associated with a reduced risk of bone fractures as well as with a higher mean bone mineral density [75,76]. The principles underlying the Mediterranean diet, recognized by UNESCO as an intangible cultural heritage of humanity [77], can be summarized as follows: high consumption of fruits, vegetables, cereals (especially whole seeds), legumes, and nuts; relatively high fat consumption (up to $40 \%$ of total energy intake), mainly as monounsaturated fatty acids from extra-virgin olive oil, the main fat used for seasoning and cooking; moderate to high consumption of fish; moderate dairy product consumption, usually in the form of yogurt and cheese; low red meat and meat product consumption; moderate alcohol consumption, mainly in the form of red wine during meals; low consumption of simple sugars (pastries, soft drinks, etc.); and high consumption of herbs and spices—an important source of micronutrients, including calcium—used to flavor dishes [78,79]. This dietary model has been shown to feature a significantly reduced level of oxidative stress thanks to its high antioxidant contents [80]. Oxidative stress occurs in fact as a result of an overproduction of oxygen free radicals not balanced by an adequate level of enzymatic and non-enzymatic antioxidants. It can damage cellular lipids, proteins, or DNA, inhibiting their physiological functions [81]. A high oxidative stress has been related to the pathogenesis of both osteoporosis and nephrolithiasis $[82,83]$. With regard to bone metabolism, reactive oxygen species directly influence both osteoblastogenesis and osteoclastogenesis. Their effects on these cell types are mediated by the same signaling cascades and factors, namely Extracellular signal-Regulated Kinase (ERKs), Nuclear Factor Kappa-light-chain-enhancer of activated B cells (NF- $\mathrm{kB}$ ), Receptor Activator of Nuclear factor Kappa-B Ligand (RANKL), Tumor Necrosing Factor (TNF), and interleukin-6, used by estrogens, however in the exact opposite manner [84,85]. In particular, reactive oxygen species impair osteoblastogenesis 
by at least two mechanisms: (1) antagonism of Wnt signaling; and (2) direct and sustained activation of ERKs and NF-KB [86]. On the other hand, reactive oxygen species inhibit osteoclast apoptosis and stimulate osteoclastogenesis by increasing RANKL production in cells of the stromal/osteoblastic lineage [87] as well as by an ERK/NF- $\mathrm{kB} / \mathrm{TNF} /$ interleukin 6-mediated mechanism [88]. With regard to nephrolithiasis, experimental and clinical studies demonstrated that high oxidative stress, especially uncontrolled lipid peroxidation, occurs in patients with nephrolithiasis [89-92]. In a model of kidney stone formation pathway proposed by Yasui and colleagues, reactive oxygen species are produced during interactions between crystals and renal cells, and are responsible for various cellular responses. In particular, calcium oxalate monohydrate crystals attach to renal tubular cells, leading to the activation of cyclophilin D. Subsequently, mitochondrial collapse and oxidative stress, with production of reactive oxygen species, occur. These events activate apoptosis, cell injury and osteopontin expression. Thereafter, collapsed mitochondria and fragmented microvilli drop off into the urine and condense into kidney stones [93].

Low physical activity. An additional lifestyle risk factor for the occurrence of both osteoporosis and nephrolithiasis may be identified in physical inactivity, which was reported to be a risk factor for both disorders, at least in post-menopausal women [94,95]. In addition, reduced physical activity prevents the achievement of an optimal peak of bone mass in children and adolescents, thus predisposing patients to osteoporosis later in life [96]. On the contrary, a moderate and constant physical activity contributes to reducing the risk of forming kidney stones by reducing weight gain and the risk of type 2 diabetes and to preserve bone mineral content [97,98]. The cellular mechanotransduction is the biological process by which physical activity regulates bone homeostasis [99] with osteocytes playing a central role in this process [100]. The major mechanosensors are the osteocyte cytoskeleton, dendritic processes, integrin-based focal adhesions, connexin-based intercellular junctions, primary cilium, ion channels, and extracellular matrix [101]. Through them, the mechanical stimuli regulate numerous cellular functions, including gene expression, protein synthesis, cell proliferation and differentiation. The dysfunctions in mechanotransduction signaling or in the osteocyte response lead to an imbalance in bone homeostasis. This alteration is very relevant in some conditions such as osteoporosis and aging [102]. Interestingly, during long-duration spaceflight in absence of gravity-mediated mechanical stimuli on the skeleton, astronauts appear to be at increased risk of both osteoporosis and nephrolithiasis [103,104].

Smoking. Cigarette smoking is also a significant risk factor for both osteoporosis and nephrolithiasis [83,84]. Cigarette smoking predisposes patients to osteoporosis by different pathophysiologic mechanisms. In effect, cigarette smoking influences the metabolism of calciotropic, cortical and sexual hormones $[105,106]$. In addition, it directly induces alteration in the RANK-Receptor Activator of NF-kB Ligand (RANKL)—osteoprotegerin (OPG) system in collagen metabolism and in bone angiogenesis. Nicotine also has an inhibitory effect on osteogenesis $[105,106]$.

On the other hand, two main mechanisms have been envisaged to explain the association between smoking and the increased risk of nephrolithiasis. First, smoking significantly increases plasma anti-diuretic hormone levels, thus decreasing urine volume and promoting urinary crystal supersaturation. The second mechanism is through increased production of reactive oxygen species resulting in increased oxidative stress and renal injury $[105,107,108]$.

Primary and secondary preventive measures. Based on the available evidence, it is not surprising that nonpharmacological interventions for a correct primary and secondary prevention of nephrolithiasis and osteoporosis are similar. Both include the avoidance of weight gain and a reduction in overweight, the avoidance of smoking and alcohol abuse and regular practice of physical activity $[97,98]$. In addition, a normal calcium/low-sodium diet $(1.2-1.5 \mathrm{~g}$ calcium/day and $<2 \mathrm{~g}$ sodium (or $5 \mathrm{~g}$ of salt)/day, respectively), with large consumption of vegetable proteins, and a water intake of at least $2 \mathrm{~L}$ per day, is recommended $[10,98,109]$. This same approach is a widely recognized valuable tool for the prevention of cardiovascular disease [110]. This type of intervention should be encouraged from childhood and adolescence. Regular physical activity in pre- and post-pubertal age 
is associated with the achievement of an optimal bone mass peak [111]. Twenty-five percent of adult bone mass is acquired at the time of pre and early puberty [111].

An adequate vitamin D status is fundamental for bone health [112-114]. However, considering the pivotal role of the vitamin D system in regulating calcium-phosphate homeostasis $[112,113]$ and the high prevalence of vitamin D deficiency (i.e., serum 25-hydroxyvitamin D levels $<50 \mathrm{nmol} / \mathrm{L}$ or $20 \mathrm{ng} / \mathrm{mL}$ ) worldwide and at all ages [113-116], the relationship between vitamin D status and susceptibility to nephrolithiasis ought to be carefully analyzed. Stone formers were found to have a high prevalence of vitamin D deficiency compared to non-stone formers [117]. Possible explanations for this association include secondary hyperparathyroidism and increased oxidative stress or inflammation in vitamin D deficiency [118]. Noteworthy, a Cochrane meta-analysis did not indicate an increased risk of hypercalcemia, hypercalciuria or nephrolithiasis in patients with vitamin D deficiency treated with cholecalciferol [119]. Moreover, the correction of vitamin D deficiency with cholecalciferol in patients with Paget's disease of the bones, who are at increased risk of nephrolithiasis [120], did not cause either an increase in supersaturation indices of calcium-oxalate and calcium-phosphate salts or a rise in urinary $\mathrm{pH}$ and urinary excretion of urate, the major risk factors for calcium and urate nephrolithiasis, respectively [121].

\subsection{Non-Modifiable Risk Factors}

The familial association of both primary osteoporosis and idiopathic stone disease has been unraveled by numerous studies, although the specific genetic and epigenetic factors have remained less clear. Both disorders seem to be genetically heterogeneous diseases related to multiple genetic factors [122,123], identified on family-based or case-control studies (Table 1).

Table 1. Genes associated to occurrence of osteoporosis and nephrolithiasis.

\begin{tabular}{cccc}
\hline Gene & HGNC Symbol & Location & Ref. \\
\hline Calcium-sensing receptor & CASR & $3 q 13.3-q 21.1$ & {$[124-126]$} \\
Vitamin D receptor & VDR & $12 q 13.11$ & {$[127-132]$} \\
Alkaline phosphatase & ALPL & $1 p 36.12$ & {$[133,134]$} \\
Osteopontin & SPP1 & $4 q 22.1$ & {$[135,136]$} \\
Claudin 14 & CLDN14 & $21 q 22.13$ & {$[137-139]$} \\
Type 2a sodium-phosphate cotransporter & SLC34A1 & $5 q 35.3$ & {$[140]$} \\
Fibroblast growth factor 23 & FGF23 & $12 p 13.32$ & {$[141]$} \\
25(OH)D-24-hydroxylase & CYP24A1 & $20 q 13.2$ & {$[142]$} \\
\hline
\end{tabular}

HGNC: Human Genome Organisation (HUGO) Gene Nomenclature Committee.

All humans carry many risk alleles for all common diseases, and each affected individual likely carries a higher burden and unique portfolio of risk variants. While the description of a polygenic model at the population level is very simply defined, it generates considerable genetic heterogeneity between individuals, which, in turn, is consistent with the characteristics of common complex diseases, such as heterogeneity in clinical presentation and variation in response to treatments. Understanding the consequences of polygenicity for individuals also links to an understanding of epistasis, the interacting effects of risk loci [143].

Calcium-sensing receptor (CASR). The calcium-sensing receptor is a plasma membrane $G$ protein-coupled receptor that is expressed in the parathyroid hormone-producing chief cells of the parathyroid gland and in the cells lining the kidney tubule. In the parathyroid gland, the CASR senses small changes in circulating calcium concentration and couples this piece of information to intracellular signaling pathways that modify PTH secretion. In the kidney, the CaSR is expressed in all tubular segments and regulates tubular cell function in response to the increase in calcium concentrations in the interstitium or tubular lumen. In the proximal tubule, the CaSR inhibits PTH-induced phosphate excretion. In addition, CaSR inhibits calcium reabsorption in the medullary thick ascending limb and water reabsorption in the collecting duct. These CaSR-mediated effects ensue 
to dilute the tubular calcium load in a larger fluid volume and decrease the risk of salt precipitation, crystal aggregation and growth, leading, in the end, to stone formation and a reduced bone mineral density [124-126,144]. Natural polymorphic variants of CASR are associated to an increased risk of both nephrolithiasis and osteoporosis, directly influencing calcium tubular handling [124-126].

Vitamin D receptor (VDR). The vitamin D receptor is an intracellular hormone receptor that specifically binds $1,25(\mathrm{OH})_{2} \mathrm{D}_{3}$ and mediates its biological effects. VDR contains a zinc-finger DNA-binding and transcriptional activation domain and a ligand-binding domain [145]. Natural polymorphic variants of VDR are associated to an increased risk of both nephrolithiasis and osteoporosis, by directly affecting calcium and citrate tubular metabolism [127-132]. In addition, a natural polymorphic variant of VDR, which lacks only the first three amino acids, was shown to interact more efficiently with its transcription factor and to possess elevated transcriptional activity. This defect resulted in an increase in 1,25-dihydroxyvitamin D3 levels, hypocalcemia with secondary hyperparathyroidism and hypophosphatemia, leading to rickets. In addition, these patients also showed increased serum alkaline phosphatase levels, generalized aminoaciduria, total alopecia and, in some cases described in an Asian population, nephrolithiasis in adults and children [146].

Alkaline phosphatase (ALPL). Alkaline phosphatase are membrane-bound glycoproteins that hydrolyze various monophosphate esters at a high $\mathrm{pH}$ optimum. The enzyme acts physiologically as a lipid-anchored phosphoethanolamine and pyridoxal-5-prime-phosphate [147]. Allelic variants of the ALPL gene have been linked to an increased risk of both osteoporosis and nephrolithiasis $[133,134]$. In addition, twenty-three allelic variants have been isolated in children affected by hypophosphatasia and kidney stones. Every mutation disrupts the spatial relationship between two essential components of the ALP active pocket in the calcium binding domain [148].

Osteopontin (SPP1). Osteopontin is a multifunctional glycosylated phosphoprotein and is a member of the small integrin-binding ligand, N-linked glycoprotein (SIBLING) family. An analysis of gene expression using microarray technology has shown that the SPP1 gene was markedly upregulated in rats during the development of calcium stone formation [149]. SPP1 seems to be involved in the early and in the late stages of the stone-forming process. In fact, that SPP1 plays a role in stimulating the deposition and adhesion of crystals to cells, due to increased adhesion tendency. Furthermore, many studies suggested that SPP1 is also an inhibitor of abnormal calcification and has a vital inhibitory role during crystallization, crystal retention, crystal congregation, and stone formation in vitro or in vivo [150,151]. Experimental studies also demonstrate that SPP1 plays a role in anchoring the osteoclasts on the bone mineral matrix, stimulated by calcitriol. In this condition, SPP1 accumulates along the bone surface and binds osteoclasts that allow local bone resorption [152]. Some polymorphic variants of SPP1 gene are associated to an increased risk of both nephrolithiasis and osteoporosis, directly influencing calcium tubular handling [135,136].

Claudin-14 (CLDN14). Claudin-14 is an integral membrane protein and a component of tight junction strands, which regulates paracellular permeability at epithelial tight junctions, and its expression is regulated by extracellular calcium changes [153]. It has been reported to be associated with levels of urinary calcium and serum parathyroid hormone and may therefore regulate bone development through its regulatory effect on calcium metabolism. Transgenic overexpression of claudin-14 in mouse kidneys generated renal defects characterized by an uncontrolled loss of calcium and magnesium [153]. Some polymorphic variants of CLDN14 gene are also associated to reduced bone mineral density in the hip and spine as well as to nephrolithiasis [137-139].

Fibroblast growth factor 23 (FGF23). Fibroblast growth factor 23 is a phosphaturic hormone whose physiological actions on renal tubule tissue are mediated by FGF receptors (FGFR) and klotho, which functions as a co-receptor, increasing the binding affinity of FGF23 for FGFRs. In the renal tubule, FGF23 regulates vitamin D metabolism and tubular phosphate reabsorption by modulating the metabolic activity of $1 \alpha 25 \mathrm{OH}$ Vitamin D Hydroxylase (Cyp27b1) and decreasing the tubular expression of type IIa sodium-phosphate cotransporter independently from PTH [154,155]. An excess of FGF23 serum levels is implicated in the pathogenesis of renal phosphate leak, a clinical 
disorder characterized by PTH- and vitamin D independent hypophosphatemia and reduced renal phosphate reabsorption [156,157]. This disorder predisposes patients to both osteoporosis and nephrolithiasis [141,156,157]. A functional allelic variant of the FGF23 gene (T239M, rs7955866) has been described in stone-forming patients with renal phosphate leak. In vitro studies showed that the T239M change increases FGF23 secretion and that the FGF23(239M) variant induces a higher activation of the FGF receptor/ERK pathway compared to FGF23(239T) [142].

Type 2a sodium-phosphate cotransporter (SLC34A1). The type 2a sodium-phosphate cotransporter (NPT2a) is expressed in the apical membrane of renal proximal tubular cells and is a key-regulator of phosphate homeostasis, modulating urinary phosphate excretion [158]. In effect, phosphate filtered by the glomerulus is subsequently reabsorbed in the proximal tubule, in which the rate-limiting step is the uptake of phosphate through NPT2a $[155,158]$. Priè et al. identified two mutations in SLC34A1 gene in two patients with a renal phosphate leak causing osteoporosis and nephrolithiasis [141]

Vitamin D 24-hydroxylase (CYP24A1). CYP24A1 is a mitochondrial enzyme responsible for inactivating vitamin D metabolites through the C-24 oxidation pathway. The 1,25-(OH)2D3 induces the 24-hydroxylase, whereas hypocalcemia, through increased parathyroid hormone, suppresses this enzyme. The mutant CYP24A1 enzymes revealed complete or near-complete loss of function, characterized by a weak binding of 1,25-dihydroxyvitamin D3 to 24-hydroxylase, leading, in the end, to hypercalcemia, nephrolithiasis and pseudovitamin D-deficient rickets $[159,160]$. A mutation of the CYP24A1 gene has been reported in a 22-year-old male patient with recurrent nephrolithiasis, nephrocalcinosis, hypercalcemia, low parathyroid hormone levels, hypercalciuria and low bone mass [142].

\section{Conclusions}

As reported in previous sections, the bulk of epidemiological and experimental data support a statistical association between idiopathic nephrolithiasis and osteoporosis, two disorders sharing many similarities with regard to environmental and genetic background. Based on such evidence, we propose to consider idiopathic nephrolithiasis and osteoporosis as the possible expressions of a unique clinical syndrome. This view involves a holistic approach to the clinical management of patients with nephrolithiasis or osteoporosis and suggests the need to evaluate the consensual occurrence of either disorder in all affected patients. On practical grounds, this holistic approach involves the assessment of metabolic risk factors for nephrolithiasis (by the measurement of 24-h urinary excretion of calcium, phosphate, citrate, magnesium and urate) in patients with osteoporosis and, conversely, the evaluation of the bone mineral density by dual-energy $\mathrm{X}$-ray absorptiometry in patients with a personal history of nephrolithiasis. In osteoporotic patients, an ultrasound examination of the abdomen should be also performed after the diagnosis of osteoporosis to evaluate the occurrence of kidney stones. This approach would guarantee the optimal treatment of most patients with either type of metabolic disorder. To this end, the development of a specific public health strategy is definitely warranted.

Author Contributions: Conceptualization, D.R., G.D.F., P.S. and A.F.; methodology, G.I. and V.A.; data analysis and interpretation, D.R., G.D.F., G.I., V.A., P.S. and A.F.; discussion of the findings, D.R., G.D.F., G.I., V.A., P.S. and A.F.; writing-original draft preparation, D.R., G.D.F., G.I., V.A., P.S. and A.F.; final editing, D.R., G.D.F., P.S. and A.F.; project administration and supervision, D.R., G.D.F., P.S. and A.F. All authors have read and agreed to the published version of the manuscript.

Funding: This research received no external funding.

Conflicts of Interest: The authors declare no conflict of interest that may be perceived as inappropriately influencing the representation or interpretation of the reported research results. 


\section{References}

1. Golden, S.H.; Robinson, K.A.; Saldanha, I.; Anton, B.; Ladenson, P.W. Clinical review: Prevalence and incidence of endocrine and metabolic disorders in the United States: A comprehensive review. J. Clin. Endocrinol. Metab. 2009, 94, 1853-1878. [CrossRef] [PubMed]

2. Cosman, F.; de Beur, S.J.; LeBoff, M.S.; Lewiecki, E.M.; Tanner, B.; Randall, S.; Lindsay, R. Clinician's guide to prevention and treatment of osteoporosis. Osteoporos. Int. 2014, 25, 2359-2381. [CrossRef]

3. Kanis, J.A.; Melton, L.J., 3rd; Christiansen, C.; Johnston, C.C.; Khaltaev, N. The diagnosis of osteoporosis. J. Bone Miner. Res. 1994, 8, 1137-1141. [CrossRef]

4. International Osteoporosis Foundation Facts and Statistics. Available online: https://www.iofbonehealth.org/ facts-statistics (accessed on 2 May 2020).

5. Ward, L.M.; Weber, D.R.; Munns, C.F.; Högler, W.; Zemel, B.S. A Contemporary View of the Definition and Diagnosis of Osteoporosis in Children and Adolescents. J. Clin. Endocrinol. Metab. 2020, 105, dgz294. [CrossRef] [PubMed]

6. Centres de Référence des Maladies Rares du Calcium et du Phosphate Protocole National de Diagnostic et de Soins (PNDS) Fragilités Osseuses Secondaires de L'enfant. Available online: https://www.has-sante.fr/ upload/docs/application/pdf/2019-10/pnds_fragilites_osseuses-27-09-2019.pdf (accessed on 31 July 2020).

7. Bianchi, M.L.; Baim, S.; Bishop, N.J.; Gordon, C.M.; Hans, D.B.; Langman, C.B.; Leonard, M.B.; Kalkwarf, H.J. Official positions of the International Society for Clinical Densitometry (ISCD) on DXA evaluation in children and adolescents. Pediatr. Nephrol. 2010, 25, 37-47. [CrossRef] [PubMed]

8. Crabtree, N.J.; Arabi, A.; Bachrach, L.K.; Fewtrell, M.; El-Hajj Fuleihan, G.; Kecskemethy, H.H.; Jaworski, M.; Gordon, C.M. Dual-energy X-ray absorptiometry interpretation and reporting in children and adolescents: The revised 2013 ISCD Pediatric Official Positions. J. Clin. Densitom. 2014, 17, 225-242. [CrossRef]

9. Laine, C.M.; Laine, T. Diagnosis of osteoporosis in children and adolescents. Eur. Endocrinol. 2013, 9, $141-144$. [CrossRef]

10. Gambaro, G.; Croppi, E.; Coe, F.; Lingeman, J.; Moe, O.; Worcester, E.; Buchholz, N.; Bushinsky, D.; Curhan, G.C.; Ferraro, P.M.; et al. Metabolic diagnosis and medical prevention of calcium nephrolithiasis and its systemic manifestations: A consensus statement. J. Nephrol. 2016, 29, 715-734. [CrossRef] [PubMed]

11. Ziemba, J.B.; Matlaga, B.R. Epidemiology and economics of nephrolithiasis. Investig. Clin. Urol. 2017, 58, 299-306. [CrossRef]

12. European Association of Urology Guidelines 2018 Edition. 2019. Available online: https://uroweb.org/wpcontent/uploads/Guidelines_WebVersion_Complete-1.pdf (accessed on 2 May 2020).

13. Sas, D.J. Dietary risk factors for urinary stones in children. Curr. Opin. Pediatr. 2020, 32, 284-287. [CrossRef]

14. Habbig, S.; Beck, B.B.; Hoppe, B. Nephrocalcinosis and urolithiasis in children. Kidney Int. 2011, 80, $1278-1291$. [CrossRef] [PubMed]

15. Copelovitch, L. Urolithiasis in children: Medical approach. Pediatr. Clin. N. Am. 2012, 59, 881-896. [CrossRef] [PubMed]

16. Zhe, M.; Hangm, Z. Nephrolithiasis as a risk factor of chronic kidney disease: A meta-analysis of cohort studies with 4,770,691 participants. Urolithiasis 2017, 45, 441-448. [CrossRef]

17. Lucato, P.; Trevisan, C.; Stubbs, B.; Zanforlini, B.M.; Solmi, M.; Luchini, C.; Girotti, G.; Pizzato, S.; Manzato, E.; Sergi, G.; et al. Nephrolithiasis, bone mineral density, osteoporosis, and fractures: A systematic review and comparative meta-analysis. Osteoporos. Int. 2016, 27, 3155-3164. [CrossRef]

18. Sakhaee, K.; Maalouf, N.M.; Poindexter, J.; Adams-Huet, B.; Moe, O.W. Relationship between urinary calcium and bone mineral density in patients with calcium nephrolithiasis. J. Urol. 2017, 197, 1472-1477. [CrossRef]

19. Chou, P.S.; Kuo, C.N.; Hung, K.S.; Chang, W.C.; Liao, Y.C.; Chi, Y.C.; Chou, W.P.; Tsai, S.J.; Liu, M.E.; Lai, C.L.; et al. Osteoporosis and the risk of symptomatic nephrolithiasis: A population-based 5-year follow-up study in Taiwan. Calcif. Tissue Int. 2014, 95, 317-322. [CrossRef]

20. Prochaska, M.; Taylor, E.; Vaidya, A.; Curhan, G. Low bone density and bisphosphonate use and the risk of kidney stones. Clin. J. Am. Soc. Nephrol. 2017, 12, 1284-1290. [CrossRef]

21. Rendina, D.; D’Elia, L.; Evangelista, M.; De Filippo, G.; Giaquinto, A.; Barone, B.; Piccinocchi, G.; Prezioso, D.; Strazzullo, P. Osteoporosis is a predictive factor for nephrolithiasis in an adult free-living Caucasian population from southern Italy: A longitudinal retrospective study based on a general practice database Calcif. Tissue Int. 2020, in press. [CrossRef] 
22. Muñoz-Garach, A.; García-Fontana, B.; Muñoz-Torres, M. Nutrients and dietary patterns related to osteoporosis. Nutrients 2020, 12, 1986. [CrossRef]

23. GBD 2017 Diet Collaborators. Health effects of dietary risks in 195 countries, 1990-2017: A systematic analysis for the Global Burden of Disease Study 2017. Lancet 2019, 393, 1958-1972. [CrossRef]

24. Strazzullo, P.; D’Elia, L.; Kandala, N.B.; Cappuccio, F.P. Salt intake, stroke, and cardiovascular disease: Meta-analysis of prospective studies. BMJ 2009, 339, b4567. [CrossRef] [PubMed]

25. Campanozzi, A.; Avallone, S.; Barbato, A.; Iacone, R.; Russo, O.; De Filippo, G.; D’Angelo, G.; Pensabene, L.; Malamisura, B.; Cecere, G.; et al. High sodium and low potassium intake among Italian children: Relationship with age, body mass and blood pressure. PLoS ONE 2015, 10, e0121183. [CrossRef] [PubMed]

26. World Health Organization. Available online: https://www.who.int/news-room/fact-sheets/detail/saltreduction (accessed on 2 May 2020).

27. Centers for Disease Control and Prevention. Available online: https://www.cdc.gov/salt/reduce_sodium_tips. htm (accessed on 2 May 2020).

28. World Action on Salt and Health. Available online: http://www.worldactiononsalt.com/ (accessed on 2 May 2020).

29. Società Italiana Nutrizione Umana. Available online: https://sinu.it/meno-sale-piu-salute/ (accessed on 2 May 2020).

30. Cappuccio, F.P.; Kalaitzidis, R.; Duneclift, S.; Eastwood, J.B. Unravelling the links between calcium excretion, salt intake, hypertension, kidney stones and bone metabolism. J. Nephrol. 2000, 13, 169-177.

31. Van der Wijst, J.; Tutakhel, O.A.Z.; Bos, C.; Danser, A.H.J.; Hoorn, E.J.; Hoenderop, J.G.J.; Bindels, R.J.M. Effects of a high-sodium/low-potassium diet on renal calcium, magnesium, and phosphate handling. Am. J. Physiol. Ren. Physiol. 2018, 315, F110-F122. [CrossRef]

32. Blackwood, A.M.; Sagnella, G.A.; Cook, D.G.; Cappuccio, F.P. Urinary calcium excretion, sodium intake and blood pressure in a multi-ethnic population: Results of the Wandsworth Heart and Stroke Study. J. Hum. Hypertens. 2001, 15, 229-237. [CrossRef]

33. Timio, F.; Kerry, S.M.; Anson, K.M.; Eastwood, J.B.; Cappuccio, F.P. Calcium urolithiasis, blood pressure and salt intake. Blood Press. 2003, 12, 122-127. [CrossRef]

34. Blaine, J.; Chonchol, M.; Levi, M. Renal control of calcium, phosphate, and magnesium homeostasis. Clin. J. Am. Soc. Nephrol. 2015, 10, 1257-1272. [CrossRef] [PubMed]

35. Haberle, D.A.; von Baeyer, D.H. Characteristics of glomerulotubular balance. Am. J. Physiol. 1983, 244, F355-F366. [CrossRef]

36. Friedman, P.A.; Gesek, F.A. Calcium transport in renal epithelial cells. Am. J. Physiol. 1993, 264, F181-F198. [CrossRef]

37. Kleeman, C.R.; Bohannan, J.; Bernstein, D.; Ling, S.; Maxwell, M.H. Effects of variations in sodium intake on calcium excretion in normal humans. Proc. Soc. Exp. Biol. Med. 1964, 115, 29-32. [CrossRef]

38. Ticinesi, A.; Nouvenne, A.; Maalouf, N.M.; Borghi, L.; Meschi, T. Salt and nephrolithiasis. Nephrol. Dial. Transplant. 2016, 31, 39-45. [CrossRef]

39. Nordin, B.E.C.; Need, A.G.; Steurer, T.; Morris, H.A.; Chatterton, B.E.; Horowitz, M. Nutrition, osteoporosis, and aging. Ann. N. Y. Acad. Sci. 1998, 854, 336-351. [CrossRef]

40. Cirillo, M.; Ciacci, C.; Laurenzi, M.; Mellone, M.; Mazzacca, G.; De Santo, N.G. Salt intake, urinary sodium, and hypercalciuria. Miner. Electrolyte Metab. 1997, 23, 265-268. [PubMed]

41. Sakhaee, K.; Harvey, J.A.; Padalino, P.K.; Whitson, P.; Pak, C.Y. The potential role of salt abuse on the risk for kidney stone formation. J. Urol. 1993, 150, 310-312. [CrossRef]

42. Moe, O.W.; Preisig, P.A. Hypothesizing on the evolutionary origins of salt-induced hypercalciuria. Curr. Opin. Nephrol. Hypertens. 2005, 14, 368-372. [CrossRef]

43. Caudarella, R.; Vescini, F.; Buffa, A.; Stefoni, S. Citrate and mineral metabolism: Kidney stones and bone disease. Front. Biosci. 2003, 8, s1084-s1106. [CrossRef] [PubMed]

44. Frings-Meuthen, P.; Baecker, N.; Heer, M. Low-grade metabolic acidosis may be the cause of sodium chloride-induced exaggerated bone resorption. J. Bone Miner. Res. 2008, 23, 517-524. [CrossRef]

45. Kirejczyk, J.K.; Korzeniecka-Kozerska, A.; Baran, M.; Porowska, H.; Porowski, T.; Wasilewska, A. Dyslipidaemia in overweight children and adolescents is associated with an increased risk of kidney stones. Acta Paediatr. 2015, 104, e407-e413. [CrossRef] [PubMed] 
46. Afsar, B.; Kiremit, M.C.; Sag, A.A.; Tarim, K.; Acar, O.; Esen, T.; Solak, Y.; Covic, A.; Kanbay, M. The role of sodium intake in nephrolithiasis: Epidemiology, pathogenesis, and future directions. Eur. J. Intern. Med. 2016, 35, 16-19. [CrossRef]

47. Rendina, D.; De Filippo, G.; D’Elia, L.; Strazzullo, P. Metabolic syndrome and nephrolithiasis: A systematic review and meta-analysis of the scientific evidence. J. Nephrol. 2014, 27, 371-376. [CrossRef]

48. Rendina, D.; D’Elia, L.; Evangelista, M.; De Filippo, G.; Giaquinto, A.; Abate, V.; Barone, B.; Piccinocchi, G.; Prezioso, D.; Strazzullo, P. Metabolic syndrome is associated to an increased risk of low bone mineral density in free-living women with suspected osteoporosis. J. Endocrinol. Investig. 2020, in press. [CrossRef] [PubMed]

49. Rendina, D.; De Filippo, G.; Zampa, G.; Muscariello, R.; Mossetti, G.; Strazzullo, P. Characteristic clinical and biochemical profile of recurrent calcium-oxalate nephrolithiasis in patients with metabolic syndrome. Nephrol. Dial. Transplant. 2011, 26, 2256-2263. [CrossRef]

50. Fatahi, S.; Namazi, N.; Larijani, B.; Azadbakht, L. The association of dietary and urinary sodium with bone mineral density and risk of osteoporosis: A systematic review and meta-analysis. J. Am. Coll. Nutr. 2018, 37, 522-532. [CrossRef] [PubMed]

51. Robinson, A.T.; Edwards, D.G.; Farquhar, W.B. The influence of dietary salt beyond blood pressure. Curr. Hypertens. Rep. 2019, 21, 42. [CrossRef]

52. Balk, E.M.; Adam, G.P.; Langberg, V.N.; Earley, A.; Clark, P.; Ebeling, P.R.; Mithal, A.; Rizzoli, R.; Zerbini, C.A.F.; Pierroz, D.D.; et al. Global dietary calcium intake among adults: A systematic review. Osteoporos. Int. 2017, 28, 3315-3324. [CrossRef]

53. Food and Agriculture Organization. Calcium Intake Levels in the United States: Issues and Considerations 2019. Available online: http://www.fao.org/3/W7336T/w7336t06.htm (accessed on 2 May 2020).

54. Gaddi, A.; Cicero, A.F.; Wani, F.O.; Dormi, A.; Pasquarelli, V.; D’Addato, S. The realization of a project aimed at reducing the plasmatic lipid level in a large Italian population improves the mean calcium daily intake: The Brisighella Study. Eur. J. Clin. Nutr. 2001, 55, 97-106. [CrossRef]

55. Curhan, G.C.; Willett, W.C.; Rimm, E.B.; Stampfer, M.J. A prospective study of dietary calcium and other nutrients and the risk of symptomatic kidney stones. N. Engl. J. Med. 1993, 328, 833-838. [CrossRef] [PubMed]

56. Marengo, S.R.; Romani, A.M. Oxalate in renal stone disease: The terminal metabolite that just won't go away. Nat. Clin. Pract. Nephrol. 2008, 4, 368-377. [CrossRef] [PubMed]

57. Borghi, L.; Schianchi, T.; Meschi, T.; Guerra, A.; Allegri, F.; Maggiore, U.; Novarini, A. Comparison of two diets for the prevention of recurrent stones in idiopathic hypercalciuria. N. Engl. J. Med. 2002, 346, 77-84. [CrossRef] [PubMed]

58. Lieske, J.C.; Tremaine, W.J.; De Simone, C.; O'Connor, H.M.; Li, X.; Bergstralh, E.J.; Goldfarb, D.S. Diet, but not oral probiotics, effectively reduces urinary oxalate excretion and calcium oxalate supersaturation. Kidney Int. 2010, 78, 178-185. [CrossRef] [PubMed]

59. DiNicolantonio, J.J.; Mehta, V.; Zaman, S.B.; O'Keefe, J.H. Not salt but sugar as aetiological in osteoporosis: A review. Mo. Med. 2018, 115, 247-252.

60. Ericsson, Y.; Angmar-Månsson, B.; Flores, M. Urinary mineral ion loss after sugar ingestion. Bone Miner. 1990, 9, 233-237. [CrossRef]

61. Douard, V.; Sabbagh, Y.; Lee, J.; Patel, C.; Kemp, F.W.; Bogden, J.D.; Lin, S.; Ferraris, R.P. Excessive fructose intake causes 1,25-(OH)(2)D(3)-dependent inhibition of intestinal and renal calcium transport in growing rats. Am. J. Physiol. Endocrinol. Metab. 2013, 304, E1303-E1313. [CrossRef] [PubMed]

62. Terada, M.; Inaba, M.; Yano, Y.; Hasuma, T.; Nishizawa, Y.; Morii, H.; Otani, S. Growth-inhibitory effect of a high glucose concentration on osteoblast-like cells. Bone 1998, 22, 17-23. [CrossRef]

63. Merlotti, D.; Gennari, L.; Dotta, F.; Lauro, D.; Nuti, R. Mechanisms of impaired bone strength in type 1 and 2 diabetes. Nutr. Metab. Cardiovasc. Dis. 2010, 20, 683-690. [CrossRef]

64. Wyshak, G.; Frisch, R.E. Carbonated beverages, dietary calcium, the dietary calcium/phosphorus ratio, and bone fractures in girls and boys. J. Adolesc. Health 1994, 15, 210-215. [CrossRef]

65. Wyshak, G. Teenaged girls, carbonated beverage consumption, and bone fractures. Arch. Pediatr. Adolesc. Med. 2000, 154, 610-613. [CrossRef] [PubMed]

66. Ma, D.; Jones, G. Soft drink and milk consumption, physical activity, bone mass, and upper limb fractures in children: A population-based case-control study. Calcif. Tissue Int. 2004, 75, 286-291. [CrossRef] 
67. Petridou, E.; Karpathios, T.; Dessypris, N.; Simou, E.; Trichopoulos, D. The role of dairy products and non alcoholic beverages in bone fractures among schoolage children. Scand. J. Soc. Med. 1997, 25, 119-125. [CrossRef] [PubMed]

68. Thom, J.A.; Morris, J.E.; Bishop, A.; Blacklock, N.J. The influence of refined carbohydrate on urinary calcium excretion. Br. J. Urol. 1978, 50, 459-464. [CrossRef]

69. Ferraro, P.M.; Taylor, E.N.; Gambaro, G.; Curhan, G.C. Soda and other beverages and the risk of kidney stones. Clin. J. Am. Soc. Nephrol. 2013, 8, 1389-1395. [CrossRef] [PubMed]

70. Denova-Gutiérrez, E.; Méndez-Sánchez, L.; Muñoz-Aguirre, P.; Tucker, K.L.; Clark, P. Dietary patterns, bone mineral density, and risk of fractures: A systematic review and meta-analysis. Nutrients 2018, 10, 1922. [CrossRef] [PubMed]

71. Odermatt, A. The Western-style diet: A major risk factor for impaired kidney function and chronic kidney disease. Am. J. Physiol. Ren. Physiol. 2011, 301, F919-F931. [CrossRef]

72. Rodriguez, A.; Curhan, G.C.; Gambaro, G.; Taylor, E.N.; Ferraro, P.M. Mediterranean diet adherence and risk of incident kidney stones. Am. J. Clin. Nutr. 2020. [CrossRef] [PubMed]

73. Leone, A.; Fernández-Montero, A.; de la Fuente-Arrillaga, C.; Martínez-González, M.Á.; Bertoli, S.; Battezzati, A.; Bes-Rastrollo, M. Adherence to the mediterranean dietary pattern and incidence of nephrolithiasis in the Seguimiento Universidad de Navarra Follow-up (SUN) Cohort. Am. J. Kidney Dis. 2017, 70, 778-786. [CrossRef] [PubMed]

74. Soldati, L.; Bertoli, S.; Terranegra, A.; Brasacchio, C.; Mingione, A.; Dogliotti, E.; Raspini, B.; Leone, A.; Frau, F.; Vignati, L.; et al. Relevance of Mediterranean diet and glucose metabolism for nephrolithiasis in obese subjects. J. Transl. Med. 2014, 12, 34. [CrossRef] [PubMed]

75. Palomeras-Vilches, A.; Viñals-Mayolas, E.; Bou-Mias, C.; Jordà-Castro, M.; Agüero-Martínez, M.; Busquets-Barceló, M.; Pujol-Busquets, G.; Carrion, C.; Bosque-Prous, M.; Serra-Majem, L.; et al. Adherence to the mediterranean diet and bone fracture risk in middle-aged women: A case control study. Nutrients 2019, 11, 2508. [CrossRef] [PubMed]

76. Malmir, H.; Saneei, P.; Larijani, B.; Esmaillzadeh, A. Adherence to mediterranean diet in relation to bone mineral density and risk of fracture: A systematic review and meta-analysis of observational studies. Eur. J. Nutr. 2018, 57, 2147-2160. [CrossRef]

77. UNESCO. Available online: https://ich.unesco.org/en/RL/mediterranean-diet-00884 (accessed on 2 May 2020).

78. Keys, A. Mediterranean diet and public health: Personal reflections. Am. J. Clin. Nutr. 1995, 61, 1321S-1323S. [CrossRef]

79. Bach-Faig, A.; Berry, E.M.; Lairon, D.; Reguant, J.; Trichopoulou, A.; Dernini, S.; Medina, F.X.; Battino, M.; Belahsen, R.; Miranda, G.; et al. Mediterranean diet pyramid today. Science and cultural updates. Public Health Nutr. 2011, 14, 2274-2284. [CrossRef]

80. Lapuente, M.; Estruch, R.; Shahbaz, M.; Casas, R. Relation of Fruits and Vegetables with Major Cardiometabolic Risk Factors, Markers of Oxidation, and Inflammation. Nutrients 2019, 11, 2381. [CrossRef]

81. Valko, M.; Leibfritz, D.; Moncol, J.; Cronin, M.T.; Mazur, M.; Telser, J. Free radicals and antioxidants in normal physiological functions and human disease. Int. J. Biochem. Cell Biol. 2007, 39, 44-84. [CrossRef]

82. Banfi, G.; Iorio, E.L.; Corsi, M.M. Oxidative stress, free radicals and bone remodeling. Clin. Chem. Lab. Med. 2008, 46, 1550-1555. [CrossRef]

83. Khan, S.R. Stress oxidative: Nephrolithiasis and chronic kidney diseases. Minerva Med. 2013, 104, 23-30. [PubMed]

84. Manolagas, S.C. Birth and death of bone cells: Basic regulatory mechanisms and implications for the pathogenesis and treatment of osteoporosis. Endocr. Rev. 2000, 2, 115-137. [CrossRef]

85. Manolagas, S.C.; Kousteni, S.; Jilka, R.L. Sex steroids and bone. Recent Prog. Horm. Res. 2002, 57, $385-409$. [CrossRef]

86. Bai, X.C.; Lu, D.; Bai, J.; Zheng, H.; Ke, Z.Y.; Li, X.M.; Luo, S.Q. Oxidative stress inhibits osteoblastic differentiation of bone cells by ERK and NF-kappaB. Biochem. Biophys. Res. Commun. 2004, 314, 197-207. [CrossRef]

87. Bai, X.C.; Lu, D.; Liu, A.L.; Zhang, Z.M.; Li, X.M.; Zou, Z.P.; Zeng, W.S.; Cheng, B.L.; Luo, S.Q. Reactive oxygen species stimulates receptor activator of NF-kappaB ligand expression in osteoblast. J. Biol. Chem. 2005, 280, 17497-17506. [CrossRef] [PubMed] 
88. Almeida, M.; Han, L.; Martin-Millan, M.; Plotkin, L.I.; Stewart, S.A.; Roberson, P.K.; Kousteni, S.; O'Brien, C.A.; Bellido, T.; Parfitt, A.M.; et al. Skeletal involution by age-associated oxidative stress and its acceleration by loss of sex steroids. J. Biol. Chem. 2007, 282, 27285-27297. [CrossRef] [PubMed]

89. Woźniak, P.; Kontek, B.; Skalski, B.; Król, A.; Różański, W.; Olas, B. Oxidative Stress and Hemostatic Parameters in Patients with Nephrolithiasis before and After Ureteroscopic Lithotripsy. Front. Physiol. 2019, 21, 799. [CrossRef]

90. Chen, J.; Zhang, D.; Ji, M.F.; Liu, T.; Mei, C.L.; Tang, X.J. Activation of liver X receptor suppresses osteopontin expression and ameliorates nephrolithiasis. J. Cell. Physiol. 2019, 234, 14109-14122. [CrossRef]

91. Zhu, J.; Wang, Q.; Li, C.; Lu, Y.; Hu, H.; Qin, B.; Xun, Y.; Zhu, Y.; Wu, Y.; Zhang, J.; et al. Inhibiting inflammation and modulating oxidative stress in oxalate-induced nephrolithiasis with the Nrf2 activator dimethyl fumarate. Free Radic. Biol. Med. 2019, 134, 9-22. [CrossRef]

92. Woźniak, P.; Kontek, B.; Różański, W.; Olas, B. The lipid peroxidation in patients with nephrolithiasis before and after extracorporeal shock wave lithotripsy. Future Med. Chem. 2018, 23, 2685-2693. [CrossRef]

93. Yasui, T.; Okada, A.; Hamamoto, S.; Ando, R.; Taguchi, K.; Tozawa, K.; Kohri, K. Pathophysiology-based treatment of urolithiasis. Int. J. Urol. 2017, 24, 32-38. [CrossRef]

94. Sorensen, M.D.; Chi, T.; Shara, N.M.; Wang, H.; Hsi, R.S.; Orchard, T.; Kahn, A.J.; Jackson, R.D.; Miller, J.; Reiner, A.P.; et al. Activity, energy intake, obesity, and the risk of incident kidney stones in postmenopausal women: A report from the Women's Health Initiative. J. Am. Soc. Nephrol. 2014, 25, 362-369. [CrossRef]

95. Booth, F.W.; Roberts, C.K.; Thyfault, J.P.; Ruegsegger, G.N.; Toedebusch, R.G. Role of inactivity in chronic diseases: Evolutionary insight and pathophysiological mechanisms. Physiol. Rev. 2017, 97, 1351-1402. [CrossRef] [PubMed]

96. Bowden Davies, K.A.; Pickles, S.; Sprung, V.S.; Kemp, G.J.; Alam, U.; Moore, D.R.; Tahrani, A.A.; Cuthbertson, D.J. Reduced physical activity in young and older adults: Metabolic and musculoskeletal implications. Ther. Adv. Endocrinol. Metab. 2019, 10. [CrossRef] [PubMed]

97. Gambaro, G.; Trinchieri, A. Recent advances in managing and understanding nephrolithiasis/nephrocalcinosis. F1000Research 2016, 5. [CrossRef] [PubMed]

98. Coronado-Zarco, R.; Olascoaga-Gómez de León, A.; García-Lara, A.; Quinzaños-Fresnedo, J.; Nava-Bringas, T.I.; Macías-Hernández, S.I. Nonpharmacological interventions for osteoporosis treatment: Systematic review of clinical practice guidelines. Osteoporos. Sarcopenia 2019, 5, 69-77. [CrossRef]

99. Pathak, J.L.; Bravenboer, N.; Klein-Nulend, J. The Osteocyte as the New Discovery of Therapeutic Options in Rare Bone Diseases. Front. Endocrinol. 2020, 11, 405. [CrossRef]

100. Uda, Y.; Azab, E.; Sun, N.; Shi, C.; Pajevic, P.D. Osteocyte Mechanobiology. Curr. Osteoporos. Rep. 2017, 15, 318-325. [CrossRef]

101. Qin, L.; Liu, W.; Cao, H.; Xiao, G. Molecular mechanosensors in osteocytes. Bone Res. 2020, 8, 23. [CrossRef]

102. Carina, V.; Della Bella, E.; Costa, V.; Bellavia, D.; Veronesi, F.; Cepollaro, S.; Fini, M.; Giavaresi, G. Bone's Response to Mechanical Loading in Aging and Osteoporosis: Molecular Mechanisms. Calcif. Tissue Int. 2020, 107, 301-318. [CrossRef]

103. Smith, S.M.; Heer, M.; Shackelford, L.C.; Sibonga, J.D.; Spatz, J.; Pietrzyk, R.A.; Hudson, E.K.; Zwart, S.R. Bone metabolism and renal stone risk during International Space Station missions. Bone 2015, 81, 712-720. [CrossRef]

104. Smith, S.M.; Zwart, S.R.; Heer, M.; Hudson, E.K.; Shackelford, L.; Morgan, J.L. Men and women in space: Bone loss and kidney stone risk after long-duration spaceflight. J. Bone Miner. Res. 2014, 29, 1639-1645. [CrossRef] [PubMed]

105. Yoon, V.; Maalouf, N.M.; Sakhaee, K. The effects of smoking on bone metabolism. Osteoporos. Int. 2012, 23, 2081-2092. [CrossRef]

106. Cusano, N.E. Skeletal Effects of Smoking. Curr. Osteoporos. Rep. 2015, 13, 302-309. [CrossRef] [PubMed]

107. Liu, C.C.; Huang, S.P.; Wu, W.J.; Chou, Y.H.; Juo, S.H.; Tsai, L.Y.; Huang, C.H.; Wu, M.T. The impact of cigarette smoking, alcohol drinking and betel quid chewing on the risk of calcium urolithiasis. Ann. Epidemiol. 2009, 19, 539-545. [CrossRef]

108. Jones, P.; Karim Sulaiman, S.; Gamage, K.N.; Tokas, T.; Jamnadass, E.; Somani, B.K. Do lifestyle factors including smoking, alcohol, and exercise impact your risk of developing kidney stone disease? Outcomes of a systematic review. J. Endourol. 2020, in press. [CrossRef] 
109. Prezioso, D.; Strazzullo, P.; Lotti, T.; Bianchi, G.; Borghi, L.; Caione, P.; Carini, M.; Caudarella, R.; Ferraro, M.; Gambaro, G.; et al. Dietary treatment of urinary risk factors for renal stone formation. A review of CLU Working Group. Arch. Ital. Urol. Androl. 2015, 87, 105-120. [CrossRef] [PubMed]

110. Iacoviello, L.; Bonaccio, M.; Cairella, G.; Catani, M.V.; Costanzo, S.; D’Elia, L.; Giacco, R.; Rendina, D.; Sabino, P.; Savini, I.; et al. Working Group for Nutrition and Stroke Diet and primary prevention of stroke: Systematic review and dietary recommendations by the ad hoc Working Group of the Italian Society of Human Nutrition. Nutr. Metab. Cardiovasc. Dis. 2018, 28, 309-334. [CrossRef]

111. Bailey, D.A.; McKay, H.A.; Mirwald, R.L.; Crocker, P.R.; Faulkner, R.A. A six-year longitudinal study of the relationship of physical activity to bone mineral accrual in growing children: The university of Saskatchewan bone mineral accrual study. J. Bone Miner. Res. 1999, 14, 1672-1679. [CrossRef] [PubMed]

112. Dusso, A.S.; Brown, A.J.; Slatopolsky, E. Vitamin D. Am. J. Physiol. Ren. Physiol. 2005, 289, F8-F28. [CrossRef] [PubMed]

113. Holick, M.F. Vitamin D deficiency. N. Engl. J. Med. 2007, 357, 266-281. [CrossRef] [PubMed]

114. Amrein, K.; Scherkl, M.; Hoffmann, M.; Neuwersch-Sommeregger, S.; Köstenberger, M.; TmavaBerisha, A.; Martucci, G.; Pilz, S.; Malle, O. Vitamin D deficiency 2.0: An update on the current status worldwide. Eur. J. Clin. Nutr. 2020, in press. [CrossRef]

115. Hagenau, T.; Vest, R.; Gissel, T.N.; Poulsen, C.S.; Erlandsen, M.; Mosekilde, L.; Vestergaard, P. Global vitamin $\mathrm{D}$ levels in relation to age, gender, skin pigmentation and latitude: An ecologic meta-regression analysis. Osteoporos. Int. 2009, 20, 133-140. [CrossRef]

116. Cashman, K.D. Vitamin D in childhood and adolescence. Postgrad. Med. J. 2007, 83, 230-235. [CrossRef]

117. Girón-Prieto, M.S.; Del Carmen Cano-García, M.; Arrabal-Polo, M.Á.; Poyatos-Andujar, A.; Quesada-Charneco, M.; de Haro-Muñoz, T.; Arias-Santiago, S.; Arrabal-Martín, M. Analysis of vitamin D deficiency in calcium stone-forming patients. Int. Urol. Nephrol. 2016, 48, 1243-1246. [CrossRef]

118. Singh, G.V.; Hampson, G.; Thomas, K.; Bultitude, M.; Willis, S. Vitamin D and kidney stones is there an association? BJU Int. 2019, 123, 751-752. [CrossRef]

119. Bjelakovic, G.; Gluud, L.L.; Nikolova, D.; Whitfield, K.; Wetterslev, J.; Simonetti, R.G.; Bjelakovic, M.; Gluud, C. Vitamin D supplementation for prevention of mortality in adults. Cochrane Database Syst. Rev. 2014, 10, CD007470. [CrossRef]

120. Rendina, D.; De Filippo, G.; Merlotti, D.; Di Stefano, M.; Mingiano, C.; Giaquinto, A.; Evangelista, M.; Bo, M.; Arpino, S.; Faraonio, R.; et al. Increased prevalence of nephrolithiasis and hyperoxaluria in Paget's disease of bone. J. Clin. Endocrinol. Metab. 2020, in press. [CrossRef]

121. Rendina, D.; De Filippo, G.; Merlotti, D.; Di Stefano, M.; Succoio, M.; Muggianu, S.M.; Bianciardi, S.; D'Elia, L.; Coppo, E.; Faraonio, R.; et al. Vitamin D status in Paget disease of bone and efficacy-safety profile of cholecalciferol treatment in pagetic patients with hypovitaminosis D. Calcif. Tissue Int. 2019, 105, 412-422. [CrossRef]

122. Ralston, S.H.; Uitterlinden, A.G. Genetics of osteoporosis. Endocr. Rev. 2010, 31, 629-662. [CrossRef]

123. Howles, S.A.; Thakker, R.V. Genetics of kidney stone disease. Nat. Rev. Urol. 2020, 17, 407-421. [CrossRef]

124. Di Nisio, A.; Rocca, M.S.; Ghezzi, M.; Ponce, M.R.; Taglianetti, S.; Plebani, M.; Ferlin, A.; Foresta, C. Calcium-sensing receptor polymorphisms increase the risk of osteoporosis in ageing males. Endocrine 2018, 61, 349-352. [CrossRef]

125. Wang, Y.B.; Guo, J.J.; Liu, Y.J.; Deng, F.Y.; Jiang, D.K.; Deng, H.W. The human calcium-sensing receptor and interleukin-6 genes are associated with bone mineral density in Chinese. Yi Chuan Xue Bao 2006, 33, 870-880. [CrossRef]

126. Vezzoli, G.; Terranegra, A.; Aloia, A.; Arcidiacono, T.; Milanesi, L.; Mosca, E.; Mingione, A.; Spotti, D.; Cusi, D.; Hou, J.; et al. Decreased transcriptional activity of calcium-sensing receptor gene promoter 1 is associated with calcium nephrolithiasis. J. Clin. Endocrinol. Metab. 2013, 98, 3839-3847. [CrossRef]

127. González-Castro, T.B.; Blachman-Braun, R.; Hernández-Díaz, Y.; Tovilla-Zárate, C.A.; Pérez-Hernández, N.; Moscardi, P.R.M.; Alam, A.; Borgonio-Cuadra, V.M.; Reyes-López, P.A.; Juárez-Rojop, I.E.; et al. Association of vitamin D receptor polymorphisms and nephrolithiasis: A meta-analysis. Gene 2019, 711, 143936. [CrossRef] [PubMed] 
128. Rendina, D.; De Filippo, G.; Gianfrancesco, F.; Muscariello, R.; Schiano di Cola, M.; Strazzullo, P.; Esposito, T. Evidence for epistatic interaction between VDR and SLC13A2 genes in the pathogenesis of hypocitraturia in recurrent calcium oxalate stone formers. J. Nephrol. 2017, 30, 411-418. [CrossRef] [PubMed]

129. Rendina, D.; Mossetti, G.; Viceconti, R.; Sorrentino, M.; Castaldo, R.; Manno, G.; Guadagno, V.; Strazzullo, P.; Nunziata, V. Association between vitamin D receptor gene polymorphisms and fasting idiopathic hypercalciuria in recurrent stone-forming patients. Urology 2004, 64, 833-838. [CrossRef] [PubMed]

130. Mossetti, G.; Rendina, D.; Viceconti, R.; Manno, G.; Guadagno, V.; Strazzullo, P.; Nunziata, V. The relationship of $3^{\prime}$ vitamin D receptor haplotypes to urinary supersaturation of calcium oxalate salts and to age at onset and familial prevalence of nephrolithiasis. Nephrol. Dial. Transplant. 2004, 19, 2259-2265. [CrossRef] [PubMed]

131. Mossetti, G.; Vuotto, P.; Rendina, D.; Numis, F.G.; Viceconti, R.; Giordano, F.; Cioffi, M.; Scopacasa, F.; Nunziata, V. Association between vitamin D receptor gene polymorphisms and tubular citrate handling in calcium nephrolithiasis. J. Intern. Med. 2003, 253, 194-200. [CrossRef] [PubMed]

132. Palsson, R.; Indridason, O.S.; Edvardsson, V.O.; Oddsson, A. Genetics of common complex kidney stone disease: Insights from genome-wide association studies. Urolithiasis 2019, 47, 11-21. [CrossRef]

133. Peris, P.; González-Roca, E.; Rodríguez-García, S.C.; Del Mar López-Cobo, M.; Monegal, A.; Guañabens, N. Incidence of mutations in the ALPL, GGPS1, and CYP1A1 genes in patients with atypical femoral fractures. JBMR Plus 2018, 3, 29-36. [CrossRef] [PubMed]

134. Alonso, N.; Larraz-Prieto, B.; Berg, K.; Lambert, Z.; Redmond, P.; Harris, S.E.; Deary, I.J.; Pugh, C.; Prendergast, J.; Ralston, S.H. Loss-of-function mutations in the ALPL gene presenting with adult onset osteoporosis and low serum concentrations of total alkaline phosphatase. J. Bone Miner. Res. 2020, 35, 657-666. [CrossRef]

135. Safarinejad, M.R.; Shafiei, N.; Safarinejad, S. Association between polymorphisms in osteopontin gene (SPP1) and first episode calcium oxalate urolithiasis. Urolithiasis 2013, 41, 303-313. [CrossRef]

136. Gao, B.; Yasui, T.; Itoh, Y.; Li, Z.; Okada, A.; Tozawa, K.; Hayashi, Y.; Kohri, K. Association of osteopontin gene haplotypes with nephrolithiasis. Kidney Int. 2007, 72, 592-598. [CrossRef]

137. Thorleifsson, G.; Holm, H.; Edvardsson, V.; Walters, G.B.; Styrkarsdottir, U.; Gudbjartsson, D.F.; Sulem, P.; Halldorsson, B.V.; de Vegt, F.; d'Ancona, F.C.; et al. Sequence variants in the CLDN14 gene associate with kidney stones and bone mineral density. Nat. Genet. 2009, 41, 926-930. [CrossRef]

138. Tang, R.; Wei, Y.; Li, Z.; Chen, H.; Miao, Q.; Bian, Z.; Zhang, H.; Wang, Q.; Wang, Z.; Lian, M.; et al. A Common variant in CLDN14 is associated with primary biliary cirrhosis and bone mineral density. Sci. Rep. 2016, 6, 19877. [CrossRef]

139. Zhang, L.; Choi, H.J.; Estrada, K.; Leo, P.J.; Li, J.; Pei, Y.F.; Zhang, Y.; Lin, Y.; Shen, H.; Liu, Y.Z.; et al. Multistage genome-wide association meta-analyses identified two new loci for bone mineral density. Hum. Mol. Genet. 2014, 23, 1923-1933. [CrossRef]

140. Prié, D.; Huart, V.; Bakouh, N.; Planelles, G.; Dellis, O.; Gérard, B.; Hulin, P.; Benqué-Blanchet, F.; Silve, C.; Grandchamp, B.; et al. Nephrolithiasis and osteoporosis associated with hypophosphatemia caused by mutations in the type 2a sodium-phosphate cotransporter. N. Engl. J. Med. 2002, 347, 983-989. [CrossRef]

141. Rendina, D.; Esposito, T.; Mossetti, G.; De Filippo, G.; Gianfrancesco, F.; Perfetti, A.; Magliocca, S.; Formisano, P.; Prié, D.; Strazzullo, P. A functional allelic variant of the FGF23 gene is associated with renal phosphate leak in calcium nephrolithiasis. J. Clin. Endocrinol. Metab. 2012, 97, E840-E844. [CrossRef]

142. Ferraro, P.M.; Minucci, A.; Primiano, A.; De Paolis, E.; Gervasoni, J.; Persichilli, S.; Naticchia, A.; Capoluongo, E.; Gambaro, G. A novel CYP24A1 genotype associated to a clinical picture of hypercalcemia, nephrolithiasis and low bone mass. Urolithiasis 2017, 45, 291-294. [CrossRef]

143. Wray, N.R.; Wijmenga, C.; Sullivan, P.F.; Yang, J.; Visscher, P.M. Common disease is more complex than implied by the core gene omnigenic model. Cell 2018, 173, 1573-1580. [CrossRef]

144. Ranieri, M. Renal $\mathrm{Ca}^{2+}$ and Water Handling in Response to Calcium Sensing Receptor Signaling: Physiopathological Aspects and Role of CaSR-Regulated microRNAs. Int. J. Mol. Sci. 2019, 20, 5341. [CrossRef] [PubMed]

145. Christakos, S.; Dhawan, P.; Verstuyf, A.; Verlinden, L.; Carmeliet, G. Vitamin D: Metabolism, Molecular Mechanism of Action, and Pleiotropic Effects. Physiol. Rev. 2016, 96, 365-408. [CrossRef] [PubMed]

146. Arita, K.; Nanda, A.; Wessagowit, V.; Akiyama, M.; Alsaleh, Q.A.; McGrath, J.A. A novel mutation in the VDR gene in hereditary vitamin D-resistant rickets. Br. J. Dermatol. 2008, 158, 168-171. [CrossRef] 
147. Weiss, M.J.; Henthorn, P.S.; Lafferty, M.A.; Slaughter, C.; Raducha, M.; Harris, H. Isolation and characterization of a cDNA encoding a human liver/bone/kidney-type alkaline phosphatase. Proc. Natl. Acad. Sci. USA 1986, 83, 7182-7186. [CrossRef]

148. Zurutuza, L.; Muller, F.; Gibrat, J.F.; Taillandier, A.; Simon-Bouy, B.; Serre, J.L.; Mornet, E. Correlations of genotype and phenotype in hypophosphatasia. Hum. Mol. Genet. 1999, 8, 1039-1046. [CrossRef]

149. Ogbureke, K.U.; Fisher, L.W. Renal expression of SIBLING proteins and their partner matrix metalloproteinases (MMPs). Kidney Int. 2005, 68, 155-166. [CrossRef] [PubMed]

150. Xie, Y.; Sakatsume, M.; Nishi, S.; Narita, I.; Arakawa, M.; Gejyo, F. Expression, roles, receptors, and regulation of osteopontin in the kidney. Kidney Int. 2001, 60, 1645-1657. [CrossRef] [PubMed]

151. Gleberzon, J.S.; Liao, Y.; Mittler, S.; Goldberg, H.A.; Grohe, B. Incorporation of osteopontin peptide into kidney stone-related calcium oxalate monohydrate crystals: A quantitative study. Urolithiasis 2019, 47, 425-440. [CrossRef] [PubMed]

152. Reinholt, F.P.; Hultenby, K.; Oldberg, A.; Heinegård, D. Osteopontin-A possible anchor of osteoclasts to bone. Proc. Natl. Acad. Sci. USA 1990, 87, 4473-4475. [CrossRef]

153. Gong, Y.; Hou, J. Claudins in barrier and transport function-the kidney. Pflugers Arch. 2017, 469, $105-113$. [CrossRef] [PubMed]

154. Fukumoto, S.; Yamashita, T. FGF23 is a hormone-regulating phosphate metabolism-Unique biological characteristics of FGF23. Bone 2007, 40, 1190-1195. [CrossRef]

155. Mossetti, G.; Rendina, D.; De Filippo, G.; Zampa, G.; Strazzullo, P. Phosphatonins: Novel insights and clinical perspectives. G. Ital. Nefrol. 2009, 26, 171-180.

156. Rendina, D.; Mossetti, G.; De Filippo, G.; Cioffi, M.; Strazzullo, P. Fibroblast growth factor 23 is increased in calcium nephrolithiasis with hypophosphatemia and renal phosphate leak. J. Clin. Endocrinol. Metab. 2006, 91, 959-963. [CrossRef]

157. Prié, D.; Beck, L.; Silve, C.; Friedlander, G. Hypophosphatemia and calcium nephrolithiasis. Nephron Exp. Nephrol. 2004, 98, e50-e54. [CrossRef]

158. Murer, H.; Hernando, N.; Forster, I.; Biber, J. Proximal tubular phosphate reabsorption: Molecular mechanisms. Physiol. Rev. 2000, 80, 1373-1409. [CrossRef]

159. Schlingmann, K.P.; Kaufmann, M.; Weber, S.; Irwin, A.; Goos, C.; John, U.; Misselwitz, J.; Klaus, G.; Kuwertz-Bröking, E.; Fehrenbach, H.; et al. Mutations in CYP24A1 and idiopathic infantile hypercalcemia. N. Engl. J. Med. 2011, 365, 410-421. [CrossRef]

160. Labuda, M.; Lemieux, N.; Tihy, F.; Prinster, C.; Glorieux, F.H. Human 25-hydroxyvitamin D 24-hydroxylase cytochrome P450 subunit maps to a different chromosomal location than that of pseudovitamin D-deficient rickets. J. Bone Miner. Res. 1993, 8, 1397-1406. [CrossRef] [PubMed]

Publisher's Note: MDPI stays neutral with regard to jurisdictional claims in published maps and institutional affiliations.

(C) 2020 by the authors. Licensee MDPI, Basel, Switzerland. This article is an open access article distributed under the terms and conditions of the Creative Commons Attribution (CC BY) license (http://creativecommons.org/licenses/by/4.0/). 